\section{The Greek Voyage}

Panagiotis Tzumakaris

Recent Graduate, History \& Secondary

Education

\section{Introduction}

Returning from a pleasant encounter with local Greeks on the island of Zante, Thomas Dallam recorded, "When our marchantes saw us, they began to be verrie angrie saying that they had soughte alaboute and thoughte that we had...com to som evell fortune; but I bid them hould ther peace, and lett me tell them my adventures."

Throughout the late 16th and 17th centuries, English travel writers were beginning to rediscover Greece which, at the time, was under Ottoman and Venetian rule. While most well-educated English travel writers began to form certain unflattering opinions about Greece, Thomas Dallam, an English organ-builder, experienced an opposing perspective. Coming from an artisan background, Dallam, unlike most classically-educated English travel writers, had few expectations for this small Mediterranean nation. Because of Dallam's upbringing and his curious nature, Dallam's perceptions of Greece differ significantly from other early English travel writers.

\footnotetext{
${ }^{1}$ J. Theodore Bent, Thomas Dallam, and John Covel. Early Voyages and Travels in the Levant. I. The Diary of Master Thomas Dallam, 1599-1600. II. Extracts from the Diaries of Dr. John Covel, 1670-1679. With Some Account of the Levant Company of Turkey Merchants, Works Issued by the Hakluyt Society ; No. 87. New York: B. Franklin, 1964, 25.
}

For England, the ability to travel into the Mediterranean predominantly stemmed from the Battle of Lepanto. Due to this naval battle, a new economic and political balance was established in the Mediterranean and the Levant Company was founded. As a result, there were higher rates of travel to the Near East from England. Thomas Dallam traveled with the merchants of the Levant Company like many of the British elites in the late sixteenth and seventeenth centuries, but his accounts on Greece provide a fresh and different perspective.

The interactions with the peoples of Greece that the early English travel writers experienced not only allow for an interesting first-hand insight of Greek life but provide reflections of the authors and their culture. The stereotypes held by the English toward Greece affected travel writers' works while abroad in those lands. The political climate of England, religious differences, and classical education are three prominent factors that shaped the perspective that English travel writers had on Greece. English travel writers tended to focus on common themes in their depictions of Greece: ancient glory versus present decline and civilization versus barbarism. While the English elites emphasized flaws in Greek society, Dallam focused purely on his experiences with the locals.

\section{The Battle of Lepanto and the Formation of the Levant Company}

The Ottoman Empire was a major power through the late sixteenth and seventeenth centuries. The Ottomans 
dominated and maintained control of the Eastern Mediterranean for centuries after the siege and sack of Constantinople in 1204. The majority of Greece, Bulgaria and the Balkans were under Ottoman rule at that time. However, several prized Greek islands were controlled by the Republic of Venice. These contested borders led to animosity between the Turks and the Venetians. In 1570, the Ottoman Empire set its sights on the island of Cyprus, which at the time was under Venetian rule. The Sultan had demanded that Venice surrender the island to his control. The Venetians refused, and with the aid of the papacy and Spain, the fourth Ottoman-Venetian War began.

The Battle of Lepanto marked a pivotal victory for the Republic of Venice and her allies. Peter Marshall suggests that the naval battle, which took place in 1571 off the western coast of modern-day Greece, deeply changed the mindset of Christian Europe. Marshall writes in his article, "Lepanto's importance as an iconic moment of respite and revival for Christian Europe, after decades of apparently inexorable Turkish advance, was to stand the test of time." Marshall expands by explaining how publications of prayers and thanksgivings were bought at English churches regarding the Turkish defeat. ${ }^{3}$

Although the Ottoman Empire was able to rebuild its fleet and capture Cyprus

\footnotetext{
${ }^{2}$ Peter Marshall, "'Rather with Papists than with Turks": The Battle of Lepanto and the Contours of Elizabethan Christendom," Reformation 17, no. 1 (2012): 136.

${ }^{3}$ Ibid, 141.
}

within the same year, the battle of Lepanto had instilled a strong sense of morale in Christian Europe. As Cayetano Rosell argues in his article:

The victory of Lepanto was neither for Venice nor Spain a decisive triumph over the perpetual enemy...It did not give liberty to Greece, it did not plant the cross beneath the walls of Constantinople; but it arrested the usurping march of the Ottoman empire; it prepared for the glorious catastrophe of Navarino. We should see in it not the beginning but the end of an heroic era... The victory of Lepanto over the Turks is the last page in the epic of their greatness.

After decades of decline in commerce between England and the Ottoman Empire, shifting waters had led to expanding trade negotiations. By the end of the $16^{\text {th }}$ century, the Levant Company had been established, allowing English merchants and travelers to visit the Ottoman Empire and more specifically, Greece more freely and frequently.

In the late sixteenth century, Queen Elizabeth, the reigning monarch of England, began to establish a fiscal relationship with the Sultan of the Ottoman Empire. England's trade revolved around mercantilism. England relied on exporting as many goods as possible in order to

\footnotetext{
${ }^{4}$ Cayetano Rosell, "The Battle of Lepanto: 1570-71," Rosseeuw St Bilaire, The Eclectic Magazine of Foreign Literature (1844-1898) 1, no. 3 (1865): 357.
} 
maximize profit. The Ottoman Empire, however, endorsed imports in favor of maximizing the supply of goods available in their vast and diverse markets. ${ }^{5}$ Commercial wealth was not the only advantage of this newly chartered trade agreement for England. According to James Theodore Bent, the Levant Company aided in England's development of art, research, geography and travel. ${ }^{6}$ Traveler writers such as Thomas Dallam, Fynes Moryson, John Covel, and George Wheler were able to visit lands previously considered restricted allowing for the rediscovery of Greece.

\section{The Anti-Greek Bias}

Through the late sixteenth and seventeenth centuries, an English education signified a classically trained individual focused on Roman literature. Efterpi Mitsi, an English literary scholar, clarifies that "Late sixteenth-century England viewed itself as a second Troy and understood the Greco-Roman world from the Roman point of view, following Virgil's and other Roman authors' anti-Greek bias." Naturally, Romans portrayed themselves as superior while regarding Greece as decadent, servile, and weak. The English travel writers' privileged and educated background shaped

\footnotetext{
${ }^{5}$ Murat Çizakça, "The Ottoman Government and Economic Life," in The Cambridge History of Turkey, edited by Suraiya N. Faroqhi and Kate Fleet, 2:. Cambridge History of Turkey, Cambridge: Cambridge University Press, 2012. 260.

${ }^{6}$ Bent, Dallam, and Covel, Early Voyages and Travels, ii.

${ }^{7}$ Efterpi Mitsi, Greece in Early English Travel Writing, 1596-1682. Cham: Palgrave Macmillan, $2017,59$.
}

a distasteful opinion about Greece and its people.

An English travel writer by the name of George Wheler inherited a small fortune which supported his studies at Lincoln College, Oxford where he became fascinated in antiquity. ${ }^{8}$ He was the son of two royalist parents who were sentenced to exile and as a result was born in the Netherlands in 1651. A year later, after the death of a relative, Wheler's family moved back to England. Starting in 1673, Wheler began touring Europe, and in 1675 in the city of Rome, met Jacob Spon. Spon would be Wheler's travelling companion on his journey to Greece and the Levant. ${ }^{9}$

One of Wheler's earlier stops in Greece was on the island of Mykonos. A prominent observation he made on this island pertained to women. Wheler described the women he encountered as "deservedly [having] a greater reputation for Beauty then Chastity." "Greek women have largely been considered exotic and erotic since 1585 when the French traveler Nicolay's travelogue was translated to English. ${ }^{11}$ He compared the Greek women of the island of Chios to nymphs which not only sexualized them, but connected them to their classical past. Mitsi writes, "[Nicolay's] depiction of the women reflect

\footnotetext{
${ }^{8}$ Ibid, 156.

${ }^{9}$ Ibid, 154-155.

${ }^{10}$ George Wheler, and Jacob Spon,. A Journey into Greece by George Wheler, Esq., in Company of Dr. Spon of Lyons: In Six Books...: With Variety of Sculptures, Early English Books Online, London: Printed for William Cademan, Robert Kettlewell, and Awnsham Churchill, 1682, 63.

${ }^{11}$ Mitsi, Greece, 71.
} 
the ambiguous position and significance of Greece in the late sixteenth century, simultaneously idealized and condemned for its fall and decadence." ${ }^{, 2}$ The stereotype of the decadent Greek, in particular the indulgent woman, is reflected by Wheler. Conversely to his remark on the lustfulness of Greek women, he continued by revealing that his captain had purchased a young woman to take with him on his travels from her father. Wheler witnessed the young woman "who with weeping and great seeming unwillingness, suffered her self to be carried to the Boat." ${ }^{13}$ Unsurprisingly, being educated in the classics, Wheler related this scene to the rape of Helen. He writes, "The History of the taking her I will not let pass without relating it, because I was by accident at the Rape of this fair Helena." ${ }^{14}$ This connection to the ancient past draws on Wheler's English education and alludes to his bias, for the portrayal of the "rape" of this young woman does not quite fit Wheler's previous accusation of the willing and promiscuous Greek women.

Wheler then proceeds to narrate that the mother of this young woman, filled with rage and bringing the rest of the women in the town to an "uproar," followed the captain to the shore. Wheler writes, "Above a hundred girls, from ten or elven, to fourteen or fifteen years old, stood with their Coats as high as their middle (I guess to signifie they were ready to accompany her, so soon as occasion offered)., ${ }^{, 15}$ Although

\footnotetext{
${ }^{12}$ Mitsi, Greece, 72.

${ }^{13}$ Wheler and Spon, A Journey into Greece, 63.

${ }^{14}$ Ibid.

${ }^{15}$ Ibid.
}

Wheler had just explained that the women were enraged that one of their own was being essentially abducted, he made the assumption that they followed her to the shore largely because, they too, wanted to be taken. This bold conclusion was made due to the predetermined belief of Greek decadence and further perpetuated negative Greek stereotypes.

Another English travel writer, Fynes Moryson, also correlated Greece with its ancient past and labeled them in an unfavorable way. The son of an affluent government official, Fynes Moryson, born in 1566 , obtained his education at Cambridge University. After acquiring his M.A., Moryson believed that remaining in England rendered him unproductive and as a result, desired to travel abroad. ${ }^{16}$ His University had provided him a license to travel "partly 'for the ornament' of his intended profession, partly because of his 'innated desire to gain experience by traveling into foreign parts." $"$ On May $1^{\text {st }}$ 1591, Moryson began his travels, and in the span of four years, had visited Germany, Switzerland, the United Provinces, Denmark, Poland, Italy, and France. ${ }^{18}$

Fynes Moryson clearly acquired an exceptional education, and as such, developed negative bias towards the Greeks

\footnotetext{
16 "Shakespeare's Europe: Unpublished Chapters of Fynes Moryson's Itinerary. Being a Survey of the Condition of Europe at the End of the Sixteenth Century; with an Introduction and an Account of Fynes Moryson's Career by Charles Hughes. London: Sherratt and Hughes. 1903." The Edinburgh Review 197, no. 404 (1903): 378.

${ }^{17}$ Ibid, 379.

${ }^{18} \mathrm{Ibid}, 380$.
} 
from the Roman literature he studied. Often, the descriptions of the Greek regions that Moryson visited were congested with Greece's glorified history and deplorable present state. One example of this is when Moryson is travelling on the island of Crete. He writes, "There was a monument of the cave of Minos, which the Candians call the sepulcher of Jupiter... [We] lodged that night... upon straw... [and] we could not buy no better meate, nor get any provender for our beasts." 19 Moryson wrote about the Greek poets that once lived in the lands he crossed, or the statues he recognized that depicted mythological heroes and combined it with his complaints about the unpleasant foods he was "forced to eate," or the "ridiculous customes" of the Greeks.

Similarly to Wheler and Moryson, John Covel's education prompted an anti-Greek bias. John Covel wrote a great deal on his travels in his many diaries. Covel was educated at Bury St. Edmunds and later Christ's College in Cambridge where he was elected to a Fellowship. ${ }^{21}$ In 1669, Covel was funded by Charles the II and the Levant Company to travel to Constantinople and act as chaplain to the ambassador upon arrival. ${ }^{22}$ Along the way, Covel was able to travel to numerous countries and regions including

\footnotetext{
${ }^{19}$ Moryson, An Itinerary Containing His Ten Yeeres Travell through the Twelve Dominions of Germany, Bohmerland, Sweitzerland, Netherland, Denmarke, Poland, Italy, Turky, France, England, Scotland \& Ireland. Glasgow : New York: J. MacLehose and Sons; The Macmillan Company, 1907, vol. II, 80.

${ }^{20}$ Ibid, 84-87.

${ }^{21}$ Bent, Dallam, and Covel. Early Voyages and Travels, xxviii.

${ }^{22}$ Ibid, xxix.
}

Greece, where he wrote extensively in his diary on the land, people, and religion.

In August of 1670, when Covel traveled to Adrianople, a city in modern-day Turkey but historically Greek, he emphasized the "curious" Greek religious customs and superstitions. Covel expressed, "You cannot imagine the strange superstition that is generally amongst the people of this country."23 Both Moryson and Covel criticized the superstitious Greeks. Yet during the same time period, England was passing statutes based on superstition. England's witchcraft statute was revived in 1563, which extended well into the mid-seventeenth century until a sharp decline in the 1670's when "relatively few alleged witches were executed." 24 Because of their anti-Greek bias, these early English travel writers almost effortlessly recorded their disapproval of the Greeks while ignoring similar flaws that existed in their nation.

\section{Civilization versus Barbarism}

A common theme amongst the writings of early English travel writers to Greece is civilization versus barbarism. In his writing, Moryson makes an assumption that the people of Greece are inherently violent which alludes to this common theme. Moryson's second journey began in December of 1595, this time with the accompaniment of his brother Henry. Their

\footnotetext{
${ }^{23} \mathrm{Ibid}, 255$.

${ }^{24}$ Julia M Garrett, "Witchcraft and Sexual Knowledge in Early Modern England." Journal for Early Modern Cultural Studies 13, no. 1 (2013): 32-72.
} 
ultimate goal was to travel to Constantinople and the Holy Land. ${ }^{25}$ Finishing their first voyage to Jerusalem and upon returning to the Venetian controlled shores, Moryson and his brother set foot on the Greek island of Cephalonia to refresh themselves on May $8^{\text {th }}, 1596 .{ }^{26}$ Evidently, from Moryson's writings in his Itinerary, it is noticeable at this brief stop that he has predetermined perceptions on Greece. Having washed their bodies on the Greek shore, Moryson writes, "Wee durst not goe farre from our Marriners, lest the inhabitants of the woodie Mountaines should offer us violence.", 27 The civilized, in Moryson's viewpoint, are himself and his counterparts. Meanwhile, the barbaric are the Greeks. Moryson's assumption that the people of Greece are inherently violent not only categorizes the Greeks as barbaric, but also emphasizes Moryson's anti-Greek bias.

In November of 1669 John Covel traveled to Peloponnese, a part of the mainland of Greece and wrote about the barbarity of the Maniotes (the Greeks native to this region). Because of the rocky terrain and mountains, the Maniotes were able to resist Ottoman occupation. Covel described them as "lawless people" that the Ottomans were unable to convert to "good order." The theme of civilization versus barbarism arose again. Instead of perceiving these Greeks as champions against their oppressors, or simply free men, they were

25 "Shakespeare's Europe", 383.

${ }^{26}$ Moryson, An Itinerary, vol. I, 455-56.

${ }^{27} \mathrm{Ibid}, 456$.

${ }^{28}$ Bent, Dallam, and Covel. Early Voyages and Travels, 133. considered barbaric. Oddly enough, the civilized party the Greeks were being compared to in this instance is not the British, but instead the Turks. According to Covel, the subjugation of the Maniotes by the Ottoman Turks would have brought unto them laws and good order.

Afraid of the lawless Greeks, the captain of the Covel's ship warned the passengers not to stray far from the Peloponnesian shore. He disclosed to them an incident that he witnessed six years prior. As stated by the captain, there was a Greek "varlet" who had approached several "Gentlemen" and had been able to deceive them into surrendering all of their belongings. ${ }^{29}$ While the varlet likely considered himself clever rather than devious and deemed the British as fools rather than gentlemen, Covel had formulated an opposing opinion. Covel writes in his Diary, "These miscreant wretches lye constantly watching upon the Rocks and the Mountains, not to secure themselves from the injuries of Pirates as themselves to Thieve and rob whom they can catch., ${ }^{30}$ Not heeding the captain's warnings, several British men began climbing up the mountains. Soon after their ascension, shots were heard. Covel witnessed that the men running back towards the shore were being chased away by Maniotes. He recounts that four men were killed by this event. ${ }^{31}$

Covel had formulated a perception of the Greeks from this altercation and his

\footnotetext{
${ }^{29}$ Ibid.

${ }^{30}$ Ibid.

${ }^{31}$ Ibid, 134-137.
} 
knowledge of Roman literature. He remarks, "I could not but call to mind old Sinon in Virgil ... Greeks are Greeks still; for falseness and treachery ... Trust them and hang them, or rather hang them first for sureness." ${ }^{32}$ It is apparent that years of study have perpetuated negative Greek stereotypes in Covel's consciousness. Had Covel not been familiar with Roman writing, he may have analyzed the situation more critically and neutrally.

The majority of Greeks had been oppressed by foreign rule for over two centuries when Covel arrived. The Maniotes, a small pocket of resistance often assaulted by the Ottomans and invading pirates, had remained free by taking advantage of the terrain and defending their mountains. Under Ottoman rule, the Greeks would have to pay devshirme, also known as a blood tax. This tax was only administered to Christian families. Military officers would rip early adolescent boys from their families, forcibly convert them to Islam, and train them to fight in the military or become civil servants. Mitsi adds, "There oppression is such that they do not even own their children."33 The Maniotes, under constant attack, would not endanger their liberty or surrender their children to a possible foreign threat. Because of Roman texts, Covel perceives the intention of the Maniotes' attack to be false-hearted and barbaric, when in fact they were being true to themselves and defending their freedom.

\footnotetext{
${ }^{32}$ Ibid, 133.

${ }^{33}$ Mitsi, Greece, 59.
}

In George Wheler's account, the theme of civilization versus barbarism is found a bit differently but exists nonetheless. When Wheler arrived in Athens, he was pleased to see that the Acropolis still existed. Mitsi explains that previous English travel writers passing by the city had little to say about it. She writes, "In [their] accounts, the deformity of the 'once worthy realm' is not even worthy of description." ${ }^{34}$ Wheler, however, writes extensively on the Parthenon and the antiquities surrounding it. He even went as far as to identify Athens "[as] a more civilized Country, than we had yet passed."35 This is quite the complement to the Athenians from the perspective of an educated English travel writer. Although Wheler described Greece in his dedication to the King, which precedes the preface, as a "Lamentable Example of the Instability of humane things," he gives Athens the honor of being the most civilized part of this deplorable nation. ${ }^{36}$

It cannot be ignored that throughout his travels in Greece, Wheler mentions the kindness, hospitality, and humanity he received from the Greek peoples. However, Wheler concluded his work by praising God for raising him as an Englishman by stating:

That he had placed the Lot of mine Inheritance in a Land that he had blessed, and hedged about for himself: where nothing is wanting to supply the defects of frail nature; but

\footnotetext{
${ }^{34}$ Ibid, 170.

${ }^{35}$ Wheler and Spon, A Journey into Greece, 335.

${ }^{36}$ Ibid, The Epistle Dedicatory.
} 
where Peace and Plenty for this many Years have seem'd to embrace each other; where every Mans Right, from the Prince to the Peasant, is secured to him by the protection of good and wholesome Laws; And more, by a King who is the Indulgent Father of his Country, and not a Tyrant: and lastly, rendered me into the Bosom of a Church, that I had often heard, but now knew, to be the most refined, pure and Orthodox Church in the World; freed from Slavery, Errour and Superstiton, and without Novelty or Confusion, established in Purity of Doctrine, Decency and Order. ${ }^{37}$

In his conclusion Wheler mentions the laws that are provided for English citizens and the faultlessness of his church, which is void of superstition. Wheler bolsters the civility of England with his praise, and in turn, implies Greece's barbarity.

\section{Hospitality Overlooked}

For the Greeks, their hospitality has withstood the test of time; this was apparent in English travel writers' accounts, even if it was largely unappreciated. The first example of unappreciated hospitality comes from the writings of Fynes Moryson. On July $4^{\text {th }}$, 1596, en route to Scanderoon from Aleppo, Moryson's brother Henry died from an illness. Efterpi Mitsi analyzes Moryson's reaction to this tragic event in her book, Greece in Early English Travel Writing, 1596-1682. She writes, "Moryson's

\footnotetext{
${ }^{37}$ Ibid, 482.
}

reference to illness in his travelogue mark his isolation, as his physical and emotional health affects not only his perception of the foreign place but also his contact with others." ${ }^{38}$ Mitsi argues that from this moment forward, Moryson's accounts of the regions he visits were heavily influenced by his brother's death.

Circumstances did little to alter Moryson's negative impression of Greece. Following his brother's death, Moryson's next Greek destination was the Venetian-ruled island of Candia, now modern-day Crete. While on the ship to the island's capital, harsh and unfavorable winds had convinced the French sailors piloting the ship that Moryson and his entourage were heretics and had to be abandoned immediately. ${ }^{39}$ Moryson was dumped on the opposite side of the island. He illustrates this scene in his Itinerary dramatically. Moryson described how ill and weak he was upon landing on the island and how, in order to advance along the beach, he was driven to fashion two swords into crutches. ${ }^{40}$ He had arrived on the island early in the morning and by noon was found by two Greek monks who took him to their monastery.

\section{At the monastery, Moryson} acknowledged the Greek monks' kindness, yet at the same time, managed to criticize them. Moryson noted, "The Caloiri or Monkes received us courteously, and gave us such victuals as they had, namely,

\footnotetext{
${ }^{38}$ Mitsi, Greece, 51.

${ }^{39}$ Moryson, An Itinerary, vol. II, 72.

${ }^{40}$ Ibid, 73.
} 
Pomegranates, Olives, Bread, and sharp

Wine, which were no good meats for sicke men." Moryson depicted himself as a dying man in his writing and when the Greek monks demonstrated their hospitality, he promptly insulted the meal he was given. In another instance in his Itinerary, Moryson wrote to the Consul of Candia so that he may be transported out of his current lodgings in the monastery to the Capital because, "[his] solitary living here... and many other things in this place, are irksome unto [him]. ${ }^{42}$ It is clear that Moryson did not genuinely appreciate the accommodations he received from the Greeks.

John Covel is the second example of largely overlooked and unappreciated Greek hospitality. Nicomedia, another historically Greek city, now situated in modern day Turkey was visited by Covel on February $22^{\text {nd }}, 1670$. He intentionally used the word "hovel" instead of house when describing the peoples' residences and labeled the city "intolerably bad, little, pittyfull, low, [and] dirty..." At the same time, Covel mentioned that he was "nobly lodged at the monastery by Greeks." "4reek hospitality is briefly commented upon and then muted in comparison to the verbal disapproval of the city as a whole.

\section{A Fresh Perspective: Thomas Dallam's Diary}

\footnotetext{
${ }^{41}$ Ibid, 74.

42 Ibid, 78.

${ }^{43}$ Bent, Dallam, and Covel. Early Voyages and Travels, 281.

${ }^{44}$ Ibid, 280.
}

An exceptional organ-builder from London, Thomas Dallam had an exceedingly different perception of Greece when he traveled there on his voyage to Constantinople in 1599. Dallam was born in the village of Lancashire and eventually moved to London, where he apprenticed at a blacksmiths' company. ${ }^{45}$ Constructing the most principle organs of his time, Dallam was chosen by Queen Elizabeth to construct an ornate organ that would be given as a gift to the Sultan of the Ottoman Empire from England. ${ }^{46}$ The Levant Company played a large role in financing Dallam's project and voyage because they were desperate to compete with their European rivals in the Mediterranean. ${ }^{47}$ Throughout his voyage to Constantinople, Dallam kept a detailed diary noting his experiences. His artisan background, which excluded a formal and upscale English education, determined his curious, excited, and open-minded perspective on his journey.

Dallam's first encounter with Greeks occurred on the island of Zante, today named Zakynthos. When the ship landed on the island, he had convinced two men travelling with him to climb the nearest mountain for a better view of the island. ${ }^{48}$ While climbing, they came across a shepherd, and one of the men accompanying Dallam up the mountain warned him to go no further "tellinge [him] that surly those that did inhahite thare weare savidge men,

\footnotetext{
${ }^{45}$ Ibid, xvi.

${ }^{46}$ Ibid, xvii.

${ }^{47}$ Mitsi, Greece, 61.

${ }^{48}$ Bent, Dallam, and Covel. Early Voyages and Travels, 20.
} 
and myghte easalye wronge us." ${ }^{49}$ At this point, Dallam refused to believe such an assumption and continued on with now only one other companion. A bit later, they came across another Greek man lying on the ground with a smile on his face. ${ }^{50}$ Being thirsty, Dallam had asked him for a drink. The man lifted a carpet and revealed six bottles of wine, one of which he poured into a silver cup and handed to Dallam. Upon finishing the glass of red wine, the man poured him a glass of white wine which Dallam exclaimed to be the best wine he ever drank. ${ }^{51}$ Dallam's companion refused to accept wine from a Greek man to which Dallam replied, "He was a foule to refuse suche a cup of wyne., ${ }^{, 52}$ In order to properly thank this Greek man, Dallam tried to pay him. The Greek man refused to accept payment. ${ }^{53}$

The hospitality of the Greeks is exemplified in this account of Dallam's Diary. Dallam, unaware of the Greek stereotypes that educated Englishmen were taught, ignored the unfounded warnings of his companions. As a result of his open-minded and curious nature, Dallam confides, "I was so well pleased with this entertaynmente. ${ }^{.54}$ Unlike the previously mentioned travel writers, Dallam appreciated the Greek man's hospitality and was not hunting for something to scrutinize.

\footnotetext{
${ }^{49} \mathrm{Ibid}$.

${ }^{50}$ Ibid, 21.

${ }^{51}$ Ibid, 22.

${ }^{52}$ Ibid.

${ }^{53}$ Ibid.

${ }^{54}$ Ibid.
}

Because of Dallam's sincerity, the Greek man had grabbed his hand and escorted him to a nearby chapel where mass was being held. Dallam described that within the chapel, the women sat on a lower level separately from the men. ${ }^{55}$ His companion, having lost sight of Dallam, entered the chapel and sat by the women, two of whom began to laugh at him. "He behaved him selfe verrie foolishly," Dallam writes. ${ }^{56}$ Dallam attempted to immerse himself in the foreign situation. Instead of criticizing the Greek Church and customs, he commented on the foolishness of his companion.

After the service had ended, Dallam and his companion exited the chapel. A Greek man had approached them and brought them to a house where they were offered food and drink. Dallam again tried to pay for the meal but the man refused to take the money. He then tried to offer the money to the young women at the house who also refused to accept it. Finally he offered a knife he was carrying to the Greek "Jentlewoman" present who "was unwilling to take, but at laste she tooke it." Once again, Dallam depicts the generosity of the Greek people.

Dallam uses the term "Jentlewoman" to describe his host. Marcus Collins explains the significance of the word "gentleman"in his article. Collins demonstrates that "the gentleman once embodied a national ideal as idiomatic and irreplaceable as the American

\footnotetext{
${ }^{55}$ Ibid, 23.

${ }^{56} \mathrm{Ibid}$.

${ }^{57}$ Ibid, 24.
} 
Dream. Its existence was once thought to be what most made the English English., ${ }^{, 58}$ This remained true until the late 1960's when the works of the state-of-the-nation unanimously endorsed that the gentleman would no longer represent English virtue. ${ }^{59}$ By referring to this Greek woman as a "Jentlewoman," Dallam is essentially suggesting that her status is on par to that of an English woman's. This is something no other English travel writer would do during the late 16th and 17th centuries.

\section{Conclusion}

The voyages of English travel writers to Greece through the late 16th and $17^{\text {th }}$ centuries stemmed from the establishment of the Levant Company. The Battle of Lepanto was a significant turning point in the $16^{\text {th }}$ century that helped facilitate the foundation of the Levant Company, which directly and indirectly funded many of the English travel writers and was the reason safe passage to Greece and the Mediterranean was possible.

While many formally educated English travel writers were influenced greatly by the negative biases ancient Roman literature contained, Thomas Dallam's lack of classical knowledge allowed him to experience Greece with a radically different perspective. In her book, Mitsi discusses an interpretation of two authors who have analyzed Dallam's work.

\footnotetext{
${ }^{58}$ Marcus Collins, "The Fall of the English Gentleman: The National Character in Decline, C. 1918-1970." Historical Research 75, no. 187 (2002): 92.

${ }^{59}$ Ibid, 109.
}

She states, "Both Danson and MacLean have defined Dallam's writing as unusually secular in tone, thus differing from the Christian and moral perspective of other travelers..." ${ }^{60}$ Moryson, Covel, and Wheler all express the civility of England while illustrating the barbarity of Greece, largely due to preconceived notions. Greece, to the educated English travel writer, represented decay, subjugation, and decadence. Greece, in Dallam's perception, represented generosity, hospitality, and phenomenal wine. 


\section{REFERENCES}

Bent, J. Theodore, Thomas Dallam, and John Covel. Early Voyages and Travels in the Levant. I. The Diary of Master Thomas Dallam, 1599-1600. II. Extracts from the Diaries of Dr. John Covel, 1670-1679. With Some Account of the Levant Company of Turkey Merchants. Works Issued by the Hakluyt Society ; No. 87. New York: B. Franklin, 1964.

Çizakça, Murat. "The Ottoman Government and Economic Life." in The Cambridge History of Turkey, edited by Suraiya N. Faroqhi and Kate Fleet, 2:. Cambridge History of Turkey, Cambridge: Cambridge University Press, 2012.

Collins, Marcus. "The Fall of the English Gentleman: The National Character in Decline, C. 1918-1970." Historical Research 75, no. 187 (2002): 92.

Garrett, Julia M. "Witchcraft and Sexual Knowledge in Early Modern England." Journal for Early Modern Cultural Studies 13, no. 1 (2013): 32-72.

Marshall, Peter. "'Rather with Papists than with Turks": The Battle of Lepanto and the Contours of Elizabethan Christendom." Reformation 17, no. 1 (2012): 136.

Mitsi, Efterpi. Greece in Early English Travel Writing, 1596-1682. Cham: Palgrave Macmillan, 2017.
Moryson. An Itinerary Containing His Ten Yeeres Travell through the Twelve Dominions of Germany, Bohmerland, Sweitzerland, Netherland, Denmarke, Poland, Italy, Turky, France, England, Scotland \& Ireland. Glasgow : New York: J. MacLehose and Sons; The Macmillan Company, 1907.

Rosell, Cayetano. "The Battle of Lepanto: 1570-71." Rosseeuw St Bilaire, The Eclectic Magazine of Foreign Literature (1844-1898) 1, no. 3 (1865): 357.

"Shakespeare's Europe: Unpublished Chapters of Fynes Moryson's Itinerary. Being a Survey of the Condition of Europe at the End of the Sixteenth Century; with an Introduction and an Account of Fynes Moryson's Career by Charles Hughes. London: Sherratt and Hughes. 1903." The Edinburgh Review 197, no. 404 (1903): 378.

Wheler, George and Jacob Spon. A Journey into Greece by George Wheler, Esq., in Company of Dr. Spon of Lyons: In Six Books...: With Variety of Sculptures. Early English Books Online, London: Printed for William Cademan, Robert Kettlewell, and Awnsham Churchill, 1682. 